\title{
A sampling of methods to study chromosome and genome structure and function
}

\author{
Beth A. Sullivan (D)
}

Received: 19 February 2020 / Revised: 19 February 2020 / Accepted: 19 February 2020 / Published online: 10 March 2020

(C) Springer Nature B.V. 2020

$\begin{array}{ll}\text { Abbreviations } \\ \text { ATAC-seq } & \text { Assay for Transposase-Accessible } \\ & \text { Chromatin sequencing } \\ \text { bp } & \text { Base pair } \\ \text { BrdU } & \text { Bromodeoxyuridine } \\ \text { Cas9 } & \text { CRISPR-associated caspase 9 } \\ \text { ChIP } & \text { Chromatin immunoprecipitation } \\ \text { CRISPR } & \text { Clustered regularly interspaced short } \\ & \text { palindromic repeats } \\ \text { CUT\&RUN } & \text { Cleavage under targets \& release using } \\ & \text { nuclease } \\ \text { DamID } & \text { DNA adenine methyltransferase } \\ & \text { identification } \\ \text { DNA } & \text { Deoxyribonucleic acid } \\ \text { DNase-seq } & \text { DNase I hypersensitive sites sequencing } \\ \text { DRIP-seq } & \text { DNA-RNA immunoprecipitation } \\ & \text { sequencing } \\ \text { GRO-seq } & \text { Global nuclear run-on sequencing } \\ \text { FISH } & \text { Fluorescence in situ hybridization } \\ \text { lncRNA } & \text { Long non-coding RNA } \\ \text { PRO-seq } & \text { Precision nuclear run-on sequencing } \\ \text { RBP } & \text { RNA-binding protein } \\ \text { RDIP } & \text { RNA-DNA immunoprecipitation } \\ \text { RNA } & \text { Ribonucleic acid } \\ & \end{array}$

Responsible Editor: Conly Rieder.

B. A. Sullivan $(\bowtie)$

Department of Molecular Genetics and Microbiology, Division of Human Genetics, Duke University School of Medicine, Durham, NC 27710, USA

e-mail: beth.sullivan@duke.edu

$\begin{array}{ll}\text { RNA-seq } & \text { Ribonucleic acid sequencing } \\ \text { seq } & \text { Sequencing } \\ \text { SNP } & \text { Single nucleotide polymorphism } \\ \text { SNS-seq } & \text { Small nascent strand sequencing } \\ \text { SV } & \text { Structural variant } \\ \text { TALE } & \text { Transcription activator-like effector } \\ \text { TE } & \text { Transposable element } \\ \text { ZFN } & \text { Zinc finger nuclease }\end{array}$

Chromosomes were termed by Waldeyer (1888), building on Theodor Boveri's description of chromatic elements and Walther Flemming's observations of the longitudinal splitting of threadlike material in the nucleus (i.e., mitosis) (reviewed in Opitz (2016)). The introduction of methods that employed synthetic or natural dyes and/or fluorochromes that differentially stain DNA based on nucleotide content or affinity to the DNA major or minor grooves allowed nuclei and chromosomes to be visualized by light or fluorescence microscopy. Giemsa (G-banding) and reverse (R-banding) were ways in which chromosome-specific banding patterns allowed accomplished cytogenetic technologists to identify deleted, duplicated, or rearranged genomic material on a single-cell basis (Comings 1975, 1978; Latt 1977). Because many of these techniques were performed on metaphase chromosomes, resolution was rather low and unable to reliably confirm submicroscopic chromosome aberrations. In the late 1980s and early 1990s, the development of fluorescence in situ hybridization with single copy, repetitive, and chromosome painting probes gave way to more precise analysis of 
the genome and allowed copy number or structural analysis of single loci to be evaluated even in interphase nuclei (Liehr et al. 2009; Ried 2013). However, nucleotide resolution cannot be achieved with molecular cytological methods, even using stretched DNA or chromatin fibers (Heiskanen et al. 1995; Sullivan 2010; Dechyeva and Schmidt 2016). Sequencing-based technologies have provided ways to interrogate the structure, organization, and packaging of the genome at base pair resolution.

The reviews within this special issue highlight techniques to address fundamental aspects of chromosome and genome biology. How chromosome and chromatin are spatially and temporally organized within the nucleus is important for understanding the interplay of genes, non-coding sequences, transcripts, and proteins in the function and regulation of the genome. Khosravi et al. (2019) discuss methods to visualize and track specific genomic regions or sequences in living cells. They review the basic framework of molecular tethering systems such as the Lac operon-Lac repressor, zinc finger nucleases (ZFNs), transcription activator-like effectors (TALEs), and clustered regularly interspaced short palindromic repeats (CRISPR) with CRISPR-associated caspase 9 (Cas9) and their uses in monitoring the dynamics of centromeres, telomeres, and individual chromosomes in plant and mammalian cells.

Numerical and structure changes to the genome are associated with birth defects, reproductive abnormalities, and cancer. The article by $\mathrm{Hu}$ et al. (2020) describes approaches ranging from classical cytogenetics to sequencing-based technologies used to identify structural chromosome rearrangements and to understand the molecular mechanisms that lead to genome rearrangements. The authors present a historical timeline of microscopy-based approaches, from early light microscopy of chromosome banding using synthetic dyes to higher resolution fluorescence microscopy approaches that use designer oligonucleotide Oligopaint probes to identify regions of chromosomes or illuminate entire chromosomes. They present genome engineering strategies to induce DNA breaks and create chromosome rearrangements or deletions that can be characterized structurally using DNA sequencing.

The Human Genome Project, initiated in the early 1990 s, set out to provide an organized and annotated base pair (bp) resolution reference assembly of a (nearly) complete human genome (Venter et al. 2001; International Human Genome Sequencing Consortium
2004). However, increasingly lower costs for whole genome sequencing has allowed many individual genomes to be compared, revealing that any two unrelated humans differ by approximately 3 million nucleotides. These heritable differences can be represented by single nucleotide polymorphisms (SNPs) or larger structural variants $(\mathrm{SV})$ that involve $>50 \mathrm{bp}$ and include deletions, insertions, duplications, or inversions. SVs can alter genome stability due to their mechanisms of formation and affect phenotypes owing to alterations in gene copy number or through position effects on nearby genes or gene clusters (Weischenfeldt et al. 2013). Balachandran and Beck (2020) review structural variation in the human genome and discuss cytological, molecular, and genomic approaches to identify SVs. They discuss the whole genome and targeted sequencing methods to identify SVs and computational tools to align sequencing reads to accurately place SVs within the genome assembly. They elaborate on how these methods will allow us to understand mechanisms of SV formation and predict the influence of SVs on genome architecture and function.

Many SVs are caused by errors in DNA replication, a fundamental nuclear process by which the genome is copied and genome integrity is maintained (MacAlpine and Bell 2005). The dynamics of DNA replication and the identification of factors involved in precisely copying the genome has been an area of intense study for decades. In less complex organisms such as bacteria or budding yeast, the origins of replication and the process of new DNA synthesis have been precisely identified and intensely studied (Brewer and Fangman 1991; Marczynski and Shapiro 1993). However, in larger eukaryotes, the process is more complicated due the increase in genome size, non-coding DNA content, and more complex chromatin structure. DNA replication occurs over a longer time frame that partitions the genome into early and late replicating regions. The identification of replication origins in large eukaryotes has been less clear so that the replication timing of the genome is typically more broadly studied. Replication dynamics have been historically studied using biochemical, molecular, and/or cytological approaches, but these methods are often laborious and are concentrated on small portions of the genome (Brewer and Fangman 1991; Boggs and Chinault 1997). Hulke et al. (2019) review contemporary genomic approaches for studying replication dynamics globally. They compare the advantages and challenges of multiple sequencing-based 
approaches, including BrdU-seq, bubble-seq, and SNSseq, and comment on the promise of single-cell replication assays that incorporate long-read sequencing technologies.

Beyond DNA replication, it is important to understand genome function more broadly. Mapping chromatin accessibility provides insight into where transcription factors bind and offer a deeper understanding of gene function and regulation. Regulation and packaging of transcriptionally active versus silent regions of the genomes are determined by how and where nucleosomes are positioned, modified histones are located, and chromatin proteins are enriched. Klein and Hainer (2019) comprehensively review methods to characterize chromatin organization and gene function. They compare and contrast the types of information that can be achieved from using approaches such as DNaseseq and ATAC-seq that map genome accessibility and discuss the unique elements of protein profiling techniques such as ChIP-seq, DamID, and CUT\&RUN. Notably, they emphasize methods that are particularly amenable to single-cell or low-input analyses.

Non-coding RNAs are a class of abundant RNAs found within the cell that are classified into multiple categories and that have functions in gene regulation, development and differentiation, and genome defense. LncRNAs have roles in nuclear compartmentalization, chromatin and chromosome organization, and other aspects of nuclear architecture. Two reviews in this special issue explore the numerous approaches to study RNAs implicated in fundamental nuclear processes. In the first article, Akkipeddi et al. (2020) zoom in on the nucleus to review types of long noncoding RNAs (lncRNAs) and their functions as molecular bridges with proteins, chromatin, and other RNAs. They discuss the range of cytological, biochemical, and genomic strategies to identify lncRNAs, with an emphasis on approaches that have been used to study the structure, function, and dynamics of specific lncRNAs within the nucleus and their relevance to disease. Methods to identify RNA-binding proteins (RBPs) in single and multi-cellular eukaryotes are compared, and the advantages and limitations of the approaches are discussed. This review illuminates the complexity of lncRNAs and introduces the reader to current questions about the roles of these non-coding elements.

The article authored by Rachel O'Neill (2020) extends the topic of nuclear non-coding RNAs by reviewing recent technological advances to identify nascent transcripts and RNAs that interact with chromatin and DNA. Dr. O'Neill provides historical context for the study of non-coding RNAs, underscoring the nuances in defining and classifying them, and highlighting key functional roles. She outlines various approaches, including RNA-seq and sequence-based nuclear run-onbased techniques (GRO-seq and PRO-seq) used to globally identify transcripts and nascent transcripts. RNADNA interactions that occur through complementary base pairing have emerged as regulators of genome and chromosome. The article outlines methods such as DRIP-seq and RDIP that globally profile RNA-DNA heteroduplexes and larger RNA-DNA-chromatin protein complexes in the context of gene regulation and 3D genome organization. Finally, the challenges of capturing and characterizing repetitive DNAs and transposable elements (TEs) genome-wide and studying their transcription and function are presented. A particular emphasis is given to the latest ultra-long-read sequencing technologies and computational pipelines required to achieve full genome assemblies that include repetitive and mobile elements.

Admittedly, this special issue covers only a few of the many methodologies used in chromosome and genome biology. Nevertheless, the articles in this issue offer a balance of historical and contemporary methodologies that are responsible for moving the field from largely microscopy-based observational experiments to highresolution genomic and functional studies. I hope that the selection of reviews presented here will offer readers new perspectives of chromosome biology and encourage them to explore the possibility of using the featured technologies in their own research.

Seven years ago, the late Professor Herbert MacGregor, founding editor of Chromosome Research, chromosome biologist, and expert in lampbrush chromosome structure and function (Gall 2018), and his CoEditor-in-Chief Dr. Conly Rieder tasked me with assembling annual special issues comprised of reviews contributed by experts in chromosome and genome research. In the special issues that I have overseen, the journal has highlighted exciting topics in chromosome research, including non-coding RNAs (2013), avian genomics (2014), Arabidopsis thaliana cytogenetics and (epi)genomics (2014), chromosome and genome engineering (2015), repetitive DNA (2015), centrosomes (2016), genome organization (2017), transposable elements (2018), and ribosomal DNA (2019). Through the special issues, I have had the privilege to 
work with many outstanding scientists in their roles as guest editors and authors. This latest special issue on Methods in Chromosome and Genome Biology is no exception-I enjoyed working with all of the authors and thank them for their excellent contributions. It is also a special issue swan song for me; since January 1st, I have moved to the role of Co-Editor-in-Chief of the journal. Going forward, Chromosome Research will continue to publish reviews as part of themed special issues; however, we also encourage submission of review articles for consideration in regular issues or as part of the Waldeyer-Flemming Special Collection. We look forward to many more years of publishing new discoveries and amazing insights into the fascinating area of chromosome biology!

\section{References}

Akkipeddi SMK, Velleca AJ, Carone DM (2020) Probing the function of long noncoding RNAs in the nucleus. Chromosom Res:1-24. https://doi.org/10.1007/s10577-01909625-x

Balachandran P, Beck CR (2020) Structural variant identification and characterization. Chromosom Res:1-17. https://doi. org/10.1007/s10577-019-09623-Z

Boggs BA, Chinault AC (1997) Analysis of DNA replication by fluorescencein situhybridization. Methods 13:259-270. https://doi.org/10.1006/meth.1997.0525

Brewer BJ, Fangman WL (1991) Mapping replication origins in yeast chromosomes. BioEssays 13:317-322. https://doi. org/10.1002/bies.950130702

Comings DE (1975) Chromosome banding. J Histochem Cytochem 23:461-462. https://doi.org/10.1177 /23.7.1095647

Comings DE (1978) Mechanisms of chromosome banding and implications for chromosome structure. Annu Rev Genet 12: 25-46. https://doi.org/10.1146/annurev. ge.12.120178.000325

Dechyeva D, Schmidt T (2016) Fluorescent in situ hybridization on extended chromatin fibers for high-resolution analysis of plant chromosomes. In: Kianian SF, Kianian PMA (eds) Plant cytogenetics. Springer, New York, pp 23-33

Gall JG (2018) Herbert Macgregor (1933-2018). Chromosom Res 26:225-231. https://doi.org/10.1007/s10577-018-9586-Z

Heiskanen M, Hellsten E, Kallioniemi O-P et al (1995) Visual mapping by fiber-FISH. Genomics 30:31-36. https://doi. org/10.1006/geno.1995.0005

Hu Q, Maurais EG, Ly P (2020) Cellular and genomic approaches for exploring structural chromosomal rearrangements. Chromosom Res:1-12. https://doi.org/10.1007/s10577-02009626-1

Hulke ML, Massey DJ, Koren A (2019) Genomic methods for measuring DNA replication dynamics. Chromosom Res:119. https://doi.org/10.1007/s10577-019-09624-y
International Human Genome Sequencing Consortium (2004) Finishing the euchromatic sequence of the human genome. Nature 431:931-945. https://doi.org/10.1038/nature03001

Khosravi S, Ishii T, Dreissig S, Houben A (2019) Application and prospects of CRISPR/Cas9-based methods to trace defined genomic sequences in living and fixed plant cells. Chromosom Res:1-11. https://doi.org/10.1007/s10577-01909622-0

Klein DC, Hainer SJ (2019) Genomic methods in profiling DNA accessibility and factor localization. Chromosom Res:1-17. https://doi.org/10.1007/s10577-019-09619-9

Latt SA (1977) Fluorescent probes of chromosome structure and replication. Can J Genet Cytol 19:603-623. https://doi. org/10.1139/g77-065

Liehr T, Mrasek K, Kosyakova N et al (2009) FISH banding techniques. In: Liehr T (ed) Fluorescence in situ hybridization (FISH) - application guide. Springer, Berlin, pp 243250

MacAlpine DM, Bell SP (2005) A genomic view of eukaryotic DNA replication. Chromosom Res 13:309-326. https://doi. org/10.1007/s10577-005-1508-1

Marczynski GT, Shapiro L (1993) Bacterial chromosome origins of replication. Curr Opin Genet Dev 3:775-782. https://doi. org/10.1016/S0959-437X(05)80098-X

O'Neill RJ, (2020) Seq'ing identity and function in a repeatderived noncoding RNA world. Chromosome Res. https://doi.org/10.1007/s10577-020-09628-z

Opitz JM (2016) Annals of morphology THEODOR BOVERI (1862-1915) to commemorate the centenary of his death and contributions to the Sutton-Boveri hypothesis. Am J Med Genet A 170:2803-2829. https://doi.org/10.1002 /ajmg.a.37693

Ried T (2013) Chromosome analysis: molecular cytogenetic approaches. In: Gelmann EP, Sawyers CL, Rauscher FJ III (eds) Molecular oncology. Cambridge University Press, Cambridge, pp 28-36

Sullivan BA (2010) Optical mapping of protein-DNA complexes on chromatin fibers. In: Bridger JM, Volpi EV (eds) Fluorescence in situ hybridization (FISH): protocols and applications. Humana Press, Totowa, pp 99-115

Venter JC, Adams MD, Myers EW, Li PW, Mural RJ, Sutton GG, Smith HO, Yandell M, Evans CA, Holt RA, Gocayne JD, Amanatides P, Ballew RM, Huson DH, Wortman JR, Zhang Q, Kodira CD, Zheng XH, Chen L, Skupski M, Subramanian G, Thomas PD, Zhang J, Gabor Miklos GL, Nelson C, Broder S, Clark AG, Nadeau J, McKusick V, Zinder N, Levine AJ, Roberts RJ, Simon M, Slayman C, Hunkapiller M, Bolanos R, Delcher A, Dew I, Fasulo D, Flanigan M, Florea L, Halpern A, Hannenhalli S, Kravitz S, Levy S, Mobarry C, Reinert K, Remington K, Abu-Threideh J, Beasley E, Biddick K, Bonazzi V, Brandon R, Cargill M, Chandramouliswaran I, Charlab R, Chaturvedi K, Deng Z, di Francesco V, Dunn P, Eilbeck K, Evangelista C, Gabrielian AE, Gan W, Ge W, Gong F, Gu Z, Guan P, Heiman TJ, Higgins ME, Ji RR, Ke Z, Ketchum KA, Lai Z, Lei Y, Li Z, Li J, Liang Y, Lin X, Lu F, Merkulov GV, Milshina N, Moore HM, Naik AK, Narayan VA, Neelam B, Nusskern D, Rusch DB, Salzberg S, Shao W, Shue B, Sun J, Wang Z, Wang A, Wang X, Wang J, Wei M, Wides R, Xiao C, Yan C, Yao A, Ye J, Zhan M, Zhang W, Zhang H, Zhao Q, Zheng L, Zhong F, Zhong W, Zhu S, Zhao S, Gilbert D, Baumhueter S, Spier G, 
Carter C, Cravchik A, Woodage T, Ali F, An H, Awe A, Baldwin D, Baden H, Barnstead M, Barrow I, Beeson K, Busam D, Carver A, Center A, Cheng ML, Curry L, Danaher S, Davenport L, Desilets R, Dietz S, Dodson K, Doup L, Ferriera S, Garg N, Gluecksmann A, Hart B, Haynes J, Haynes C, Heiner C, Hladun S, Hostin D, Houck J, Howland T, Ibegwam C, Johnson J, Kalush F, Kline L, Koduru S, Love A, Mann F, May D, McCawley S, McIntosh T, McMullen I, Moy M, Moy L, Murphy B, Nelson K, Pfannkoch C, Pratts E, Puri V, Qureshi H, Reardon M, Rodriguez R, Rogers YH, Romblad D, Ruhfel B, Scott R, Sitter C, Smallwood M, Stewart E, Strong R, Suh E, Thomas R, Tint NN, Tse S, Vech C, Wang G, Wetter J, Williams S, Williams M, Windsor S, Winn-Deen E, Wolfe K, Zaveri J, Zaveri K, Abril JF, Guigó R, Campbell MJ, Sjolander KV, Karlak B, Kejariwal A, Mi H, Lazareva B, Hatton T, Narechania A, Diemer K, Muruganujan A, Guo N, Sato S, Bafna V, Istrail S, Lippert R, Schwartz R, Walenz B, Yooseph S, Allen D, Basu A, Baxendale J, Blick L, Caminha M, Carnes-Stine J, Caulk P, Chiang YH, Coyne M, Dahlke C, Mays A, Dombroski M, Donnelly M, Ely D, Esparham S, Fosler C, Gire H, Glanowski S, Glasser K, Glodek A,
Gorokhov M, Graham K, Gropman B, Harris M, Heil J, Henderson S, Hoover J, Jennings D, Jordan C, Jordan J, Kasha J, Kagan L, Kraft C, Levitsky A, Lewis M, Liu X, Lopez J, Ma D, Majoros W, McDaniel J, Murphy S, Newman M, Nguyen T, Nguyen N, Nodell M, Pan S, Peck J, Peterson M, Rowe W, Sanders R, Scott J, Simpson M, Smith T, Sprague A, Stockwell T, Turner R, Venter E, Wang M, Wen M, Wu D, Wu M, Xia A, Zandieh A, Zhu X (2001) The sequence of the human genome. Science 291:1304-1351. https://doi.org/10.1126/science. 1058040

Waldeyer W (1888) Ueber Karyokinese und ihre Beziehungen zu den Befruchtungsvorgängen. Arch Für Mikrosk Anat 32:1122. https://doi.org/10.1007/BF02956988

Weischenfeldt J, Symmons O, Spitz F, Korbel JO (2013) Phenotypic impact of genomic structural variation: insights from and for human disease. Nat Rev Genet 14:125-138. https://doi.org/10.1038/nrg3373

Publisher's note Springer Nature remains neutral with regard to jurisdictional claims in published maps and institutional affiliations. 